\title{
Absence of experimental cross-protection induced by a Trypanosoma cruzi-like strain isolated from bats
}

\author{
Ausência de proteção cruzada experimental induzida \\ por uma cepa Trypanosoma cruzi-like isolada de morcego
}

\author{
Gabriel Antonio Nogueira Nascentes ${ }^{1}$, Wendell Sérgio Ferreira Meira ${ }^{1}$, \\ Eliane Lages-Silva ${ }^{1}$ and Luis Eduardo Ramírez ${ }^{1}$
}

\begin{abstract}
This study evaluated the possibility of inoculation and reinoculation with a trypanosomatid isolated from bats that is morphologically, biologically and molecularly similar to Trypanosoma cruzi, to protect against infection by virulent strains. Non-isogenic mice were divided into 24 groups that received from zero to three inoculations of Trypanosoma cruzi-like strain RM1, in the presence or absence of Freund's adjuvant, and were challenged with the VIC or JG strains of Trypanosoma cruzi. Parasitemia and survival were monitored and animals were sacrificed for histopathological analysis. Animals immunized with Trypanosoma cruzi-like strain RM1 presented decreased parasitemia, independently of the number of inoculations or the presence of adjuvant. In spite of this reduction, these animals did not present any protection against histopathological lesions. Severe eosinophilic infiltrate was observed and was correlated with the number of inoculations of Trypanosoma cruzi-like strain RM1. These findings suggest that prior inoculation with this strain did not protect against infection but, rather, aggravated the tissue inflammatory process.
\end{abstract}

Key-words: Trypanosoma cruzi. Trypanosoma cruzi-like. Bat trypanosomatids. Cross-protection. Eosinophils.

\section{RESUMO}

Este trabalho avaliou a possibilidade da inoculação e reinoculação de um tripanossomatídeo isolado de morcego, morfológica, biológica e molecularmente semelhante ao Trypanosoma cruzi, na proteção contra a infecção por cepas virulentas. Camundongos não-isogênicos foram divididos em 24 grupos, que receberam de zero a três inóculos da cepa RM1 de Trypanosoma cruzi-like, na presença ou ausência de adjuvante de Freund e desafiados com as cepas de Trypanosoma cruzi VIC ou JG. Acompanhou-se a parasitemia e a sobrevida e os camundongos foram sacrificados para análise histopatológica. Os animais imunizados com a cepa RM1 de Trypanosoma cruzi-like apresentaram redução da parasitemia, independente do número de inóculos ou presença de adjuvante. Apesar dessa redução, os animais não apresentaram proteção contra lesões histopatológicas e observaram-se intensos infiltrados eosinofílicos que foram correlacionados com o número de inóculos da cepa RM1 de Trypanosoma cruzi-like. Sugere-se que a inoculação prévia dessa cepa, ao invés de proteger contra a infecção, agravou o processo inflamatório tecidual.

Palavras-chaves: Trypanosoma cruzi. Trypanosoma cruzi-like. Tripanossomatídeos de morcego. Proteção cruzada. Eosinófilos.

According to the World Health Organization ${ }^{38}$, eight million people are currently infected with Trypanosoma cruzi in Latin America. Various measures have been proposed for effective control over Chagas disease, such as vector combat, housing improvement, prevention of transfusional transmission, animal reservoir control and research aimed towards obtaining an effective vaccine ${ }^{16}$.

Some of these investigations have involved cross-protection mechanisms using strains isolated from human cases ${ }^{1328}$, trypanosomatid strains isolated from different reservoirs ${ }^{79} 3136$ and, more recently, DNA vaccines or recombinant proteins ${ }^{1435}$.
Heterologous immunization has been important due to associations between similar antigens from different trypanosomatids, in comparison with Trypanosoma cruzi, and their absence of pathogenicity for the vertebrate host. Several organisms have already been used in experimental models, like Leptomonas pessoa $i^{36}$, Phytomonas serpens ${ }^{91}$ and Trypanosoma rangeli ${ }^{7}$, demonstrating partial protection. Nonetheless, the high variety of trypanosomatids circulating in animal reservoirs is still unknown. In many cases, the morphological but not biological characteristics of these trypanosomes coincide with what is obtained from Trypanosoma cruzi strains in human cases,

\footnotetext{
1. Disciplina de Parasitologia, Departamento de Ciências Biológicas, Universidade Federal do Triângulo Mineiro, Uberaba, MG. Supported by CNPq (Grant 301375/2005-4), CAPES, UFTM-FUNEPU

Address to: Prof. Luis Eduardo Ramírez. Disc. de Parasitologia/DCB/UFMTM. Av. Frei Paulino 30, 38025-180 Uberaba, MG.

Tel: $55343318-5207$

e-mail: parasito_fmtm@mednet.com.br

Recebido para publicação em: 01/09/2007

Aceito em: 28/03/2008
} 
which leads to classification of these species as Trypanosoma cruzi-like. In some previous studies, cross-protection assays were performed by using trypanosomatids isolated from bats against virulent strains of Trypanosoma cruzi ${ }^{2}{ }^{18}$. In spite of the decreased parasitemia and increased survival among immunized animals, the parasites isolated in those cases were also able to infect mice, thus suggesting that these trypanosomes could be a particular strain of Trypanosoma cruzi.

In a recent study by Bento ${ }^{8}$ at the Federal University of the Triângulo Mineiro (UFTM), a trypanosome strain was isolated from the bat Phyllostomus hastatus that is morphologically, biologically and molecularly similar to Trypanosoma cruzi but was unable to infect mice and was named Trypanosoma cruzi-like strain RM1. From this, a pilot study on experimental cross-protection was developed against a highly virulent strain of Trypanosoma cruzi (VIC strain), and the results showed significantly decreased parasitemia and increased survival among the animals inoculated with this strain (unpublished data).

By means of parasitological and histopathological analysis, in the present study we evaluated the induction of cross-protection by Trypanosoma cruzi-like strain RM1 that had previously been inoculated into mice, after challenging with different Trypanosoma cruzi strains.

\section{MATERIAL AND METHODS}

For this study, 236 non-isogenic Swiss mice were divided into 24 groups that received from zero to three inoculations of Trypanosoma cruzi-like strain RM1, in the presence or absence of Freund's adjuvant. These were then challenged with the VIC or JG strains of Trypanosoma cruzi or maintained as uninfected controls. Thus, the experimental model groups covered all the studied variables (Table 1).

The Trypanosoma cruzi-like strain RM1 was maintained in liver infusion tryptose medium (LIT) ${ }^{12}$ and, for inoculations, the parasites were washed in saline and counted in a Neubauer chamber for volume correction to $3.0 \times 10^{6}$ parasites $/ 0.1 \mathrm{ml}$, inoculated intraperitoneally in the mice. In the presence of adjuvant, an emulsion with saline was prepared, using the same volume, and subcutaneously inoculated. For the prime immunization of the animals, complete Freund's adjuvant was used, and this was replaced by incomplete adjuvant in subsequent inoculations.

The challenge was undertaken using the VIC ${ }^{32}$ and JG strains of Trypanosoma cruzi (E Lages-Silva: personal communication, 1995). The parasitemia peaks were synchronized so that infections were performed for both strains on the same day. The inoculum was prepared using the method described by Brener ${ }^{10}$, using $25 \times 10^{3}$ trypomastigotes for the VIC strain and $35 \times 10^{3}$ for the JG strain. The inoculations respected a 30-day interval and, between these, two animals in each group inoculated with Trypanosoma cruzi-like strain RM1 were evaluated with regard to infection effectiveness, by means of microhematocrit.

After challenging with the Trypanosoma cruzi strains, the parasitemia was monitored in three animals from each group, for the whole patent period. During the subpatent period, blood cultures (LIT medium) were randomly performed on three animals in each group. Survival was monitored for 70 days and then the same animals that had been randomly selected for blood culturing were sacrificed by means of asphyxiation in an ether chamber. Tissue specimens from the liver, spleen, adrenal glands, heart, testicles, skeletal muscle, diaphragm, bladder, lymph nodes, esophagus and gastrointestinal junctions (esophagogastric, gastroduodenal and ileocecal) were collected, washed with saline and fixed in $10 \%$ buffered formalin solution for at least 48 hours. The tissue specimens were dehydrated in alcohol, diaphanized in xylene and embedded in paraffin. Following this, two sections of thickness $4-5 \mu \mathrm{m}$ from each of the tissue types from each mouse were stained using the hematoxylin-eosin technique (HE), with the aim of identifying parasitic nests and semiquantitatively classifying the tissue inflammatory processes as absent $(-)$, slight $(+)$, moderate $(++)$ or severe $(+++)^{2134}$.

The parasitemia data were subjected to the Mann-Whitney nonparametric test or the Kruskal-Wallis test, followed by the post-hoc Dunn test, and the results were expressed as medians.

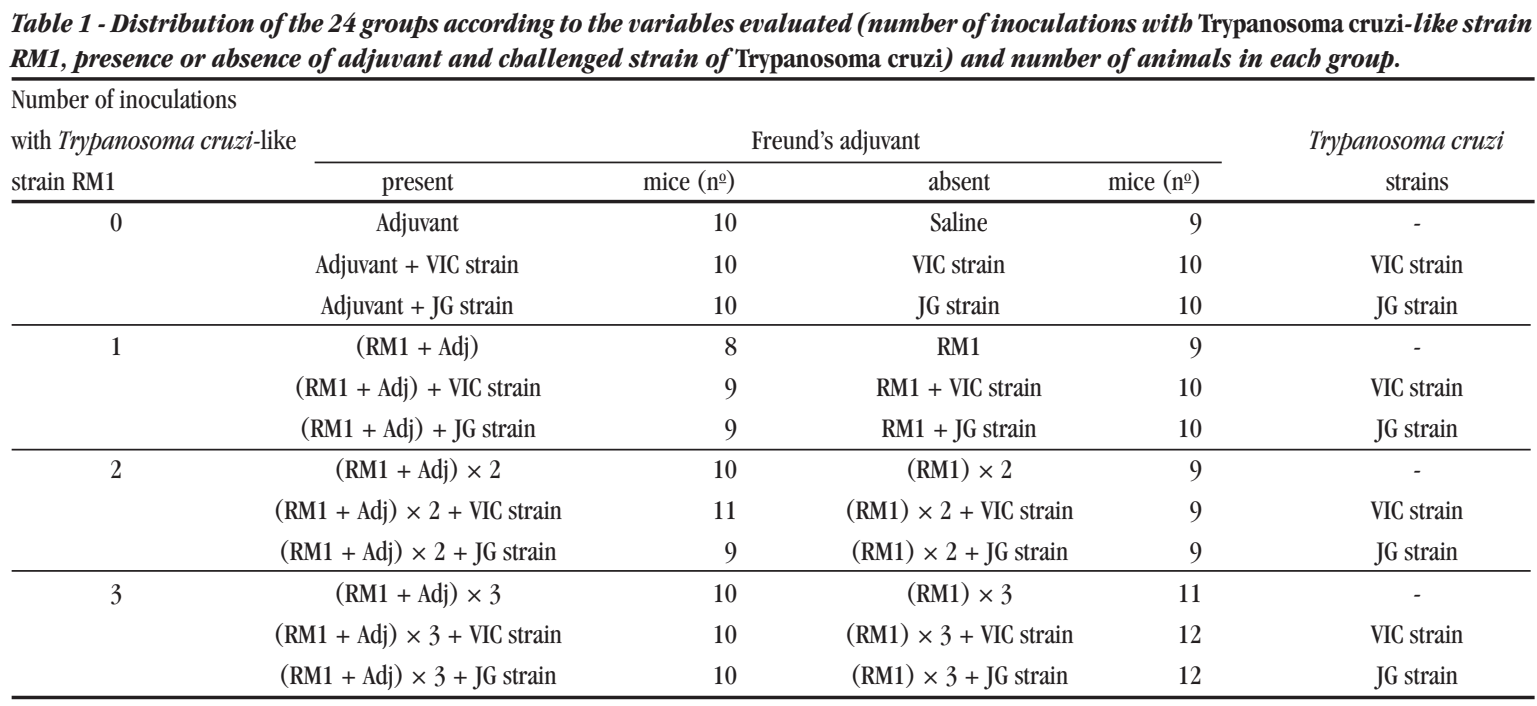


Survival was evaluated by means of the Kaplan-Meier productlimit method and the Cox-Mantel test was applied. Furthermore, the final survival percentages were subjected to the chi-square test. Tissue parasitism and histopathological lesions among the groups were compared using the chi-square test. All analyses were performed using the Statistica software, version 7.0, and p-values $<0.05$ were taken to be significant.

The present work was approved by the Animal Use Ethics Committee of the Federal University of the Triângulo Mineiro (Protocol no 48)

\section{RESULTS}

Trypanosoma cruzi-like strain RM1 did not demonstrate infectivity or pathogenicity towards mice, as shown by the negative results from of all microhematocrit and blood culturing tests and by the normal appearance of all muscle tissues evaluated. In lymphoid organs, there was a positive association between reactivity and number of inoculations with Trypanosoma cruzilike strain RM1. In the liver, diffuse inflammatory processes were observed, which damaged portal spaces and hepatic lobes in animals with three immunizations. However, there was no significant association between the number of inoculations and severity of hepatic lesions. Survival was similar among the non-challenged control groups, independently of the number of inoculations or presence of adjuvant, and reached more than $66.7 \%$, depending on the treatment received by the group.

In the groups challenged with Trypanosoma cruzi strains, the prepatent period ranged from four to nine days. Among the mice infected with the JG strain, the patent period was longer than among those infected with the VIC strain.

The presence of adjuvant was a partial protective factor only when inoculated in association with Trypanosoma cruzi-like strain RM1, due to decreased parasitemia in the groups challenged with the JG strain. In animals challenged with the VIC strain, the pattern of the parasitemia curve was similar among the groups immunized with Trypanosoma cruzi-like strain RM1, in the presence or absence of adjuvant (Figures $1 \mathrm{~A}$ and $1 \mathrm{~B}$ ). Evaluation of the effect of the adjuvant without any association showed that it prompted a partially negative factor, due to increased parasitemia in the groups challenged with the VIC strain. Among those infected with the JG strain, there were no differences between the groups not immunized with Trypanosoma cruzi-like strain RM1 that received only adjuvant and those that received saline (Figures 1C and 1D).

Regarding the number of inoculations with Trypanosoma cruzi-like strain RM1, there were no significant differences in the parasitemia curves among the groups with one, two or three inoculations. Nevertheless, it became clear that a single immunization was enough to observe decreased parasitemia in groups that received Trypanosoma cruzi-like strain RM1, in comparison with non-immunized groups (Figures $1 \mathrm{E}$ and $1 \mathrm{~F}$ ). Survival analysis on the challenged mice did not show any significant differences among the groups, and it reached more than $60 \%$, depending on the immunization strategy, such as in the control groups.

The presence of amastigote nests was confirmed in infections with both Trypanosoma cruzi strains (VIC and JG), and there were no statistical differences between immunized and nonimmunized groups, regarding tissue parasitism. The JG strain showed greater infectivity than the VIC strain did, which was shown by the greater number of tissue types with the parasite and the rate of positive findings from histopathological examination. Nonetheless, in some tissues, the VIC strain presented greater severity of histopathological damage than the JG strain did.

With regard to the effects of Trypanosoma cruzi-like strain RM1 immunization in the histopathological lesions, there

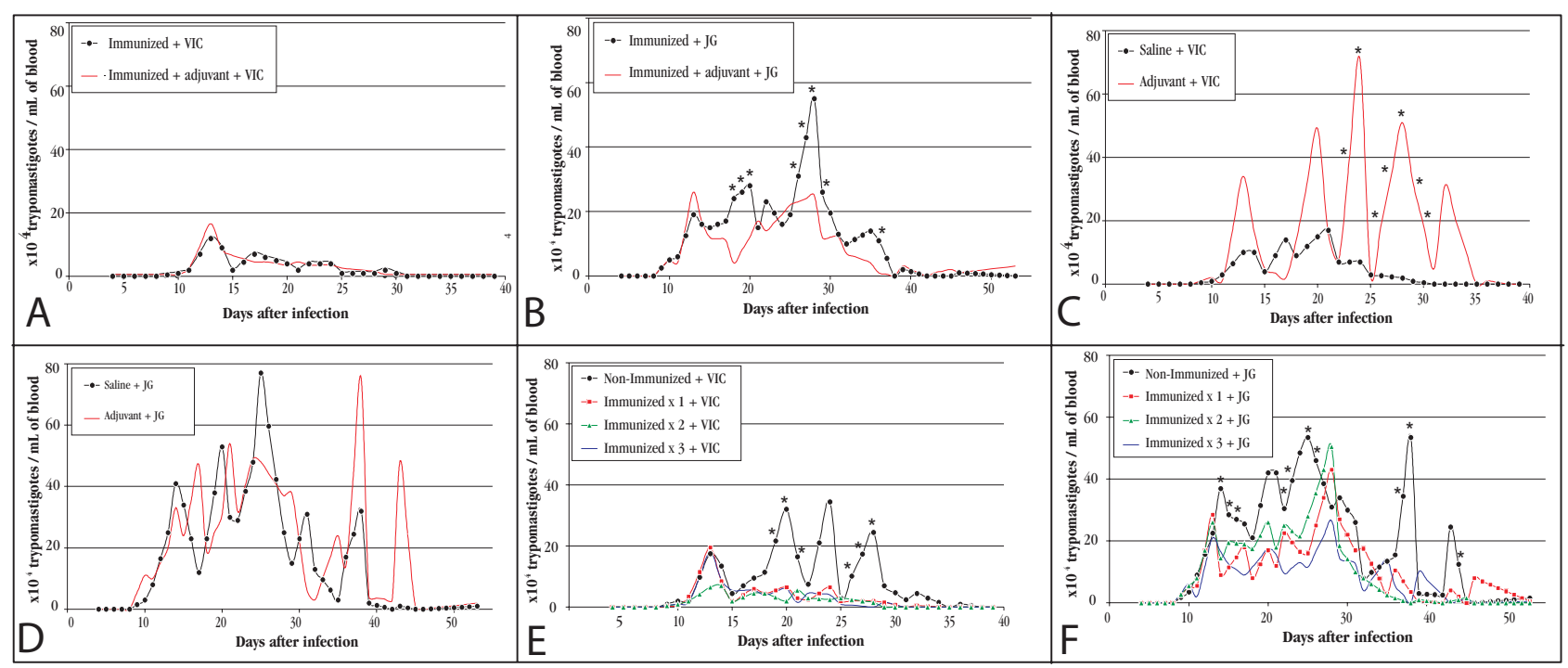

Figure 1 - Parasitemia curves ("p < 0.05). A and B - groups immunized with Trypanosoma cruzi-like strain RM1 in the presence or absence of adjuvant, independently of the number of inoculations, and challenged with VIC strain (A) or JG strain (B); C and D - groups not immunized with Trypanosoma cruzi-like strain RM1 that received only adjuvant or saline and infected with VIC strain (C) or JG strain (D); $E$ and $F$ - mice challenged with VIC strain (E) or JG strain (F), according to the number of immunizations with Trypanosoma cruzi-like strain RM1, independently of adjuvant presence, and non-immunized control groups. 
were no significant differences among the groups. However, in several tissue samples analyzed, the frequency and intensity of the inflammatory processes were higher in mice immunized with Trypanosoma cruzi-like strain RM1, independently of the number of inoculations and the Trypanosoma cruzi strain used for the challenge.

In general, the pathological processes were focal or multifocal. Occasionally, they were diffuse, with variable intensity, and in some cases, they demonstrated muscle fiber destruction. The cellular infiltrates were observed to be characteristically mononuclear or polymorphonuclear, and one important discovery was the presence of severe eosinophilia, particularly in skeletal muscle (Figure 2). Therefore, the intensity of tissue eosinophils was compared by taking into consideration the Trypanosoma cruzilike strain RM1 immunization and, likewise, the number of inoculations. Although the analysis showed that the difference was statistically nonsignificant, eosinophils were found to be more frequently present in immunized mice (Figure $3 \mathrm{~A}$ ), while they demonstrated higher intensity in those groups that received more than one inoculum of Trypanosoma cruzi-like strain RM1, when the number of immunizations was evaluated (Figure 3B).
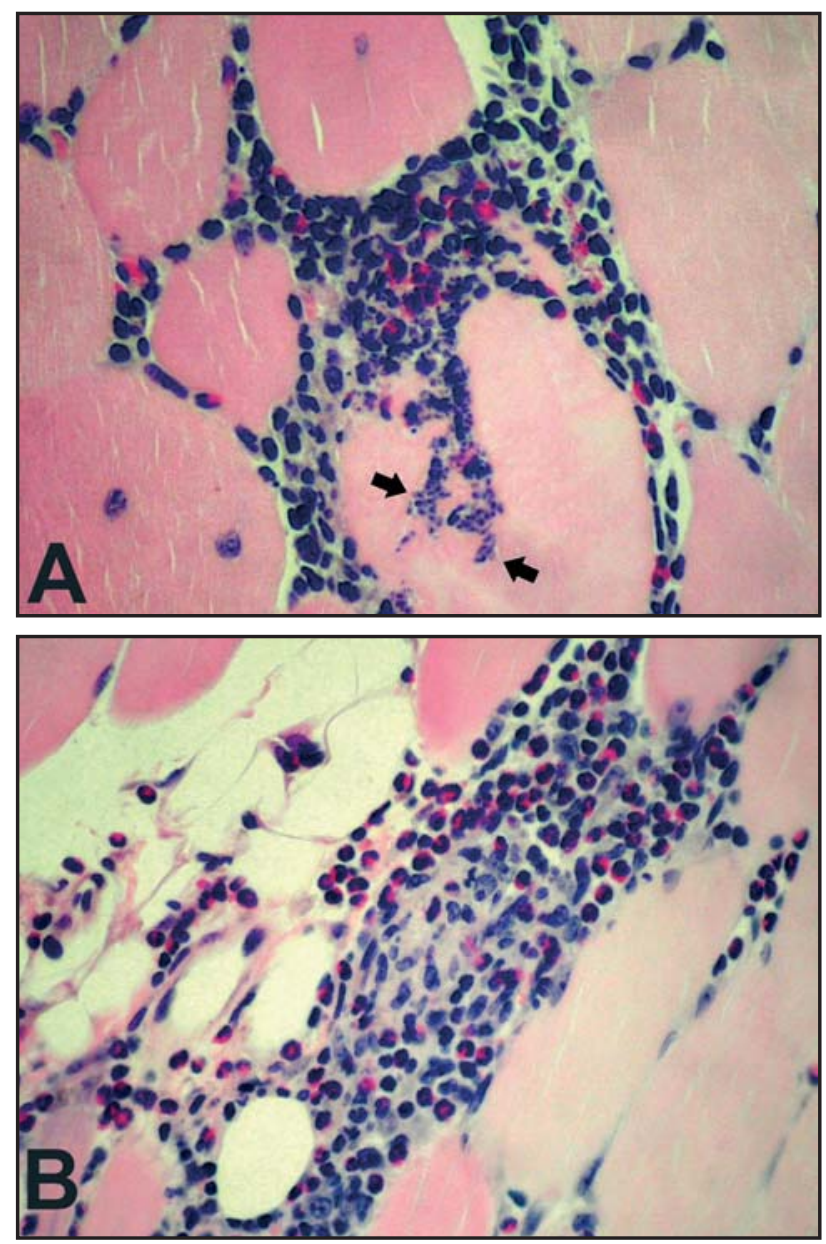

Figure 2 - Skeletal muscle showing severe eosinophil infiltrates, with destruction of muscle fibers due to the inflammatory process itself or associated with amastigote nests (see arrows, Figure 2 A) (HE, 400×). ANon-immunized mice with Trypanosoma cruzi-like strain RM1, infected withJG strain; B - Mice immunized with three inoculums of Trypanosoma cruzi-like strain RM1 and challenged with JG strain.

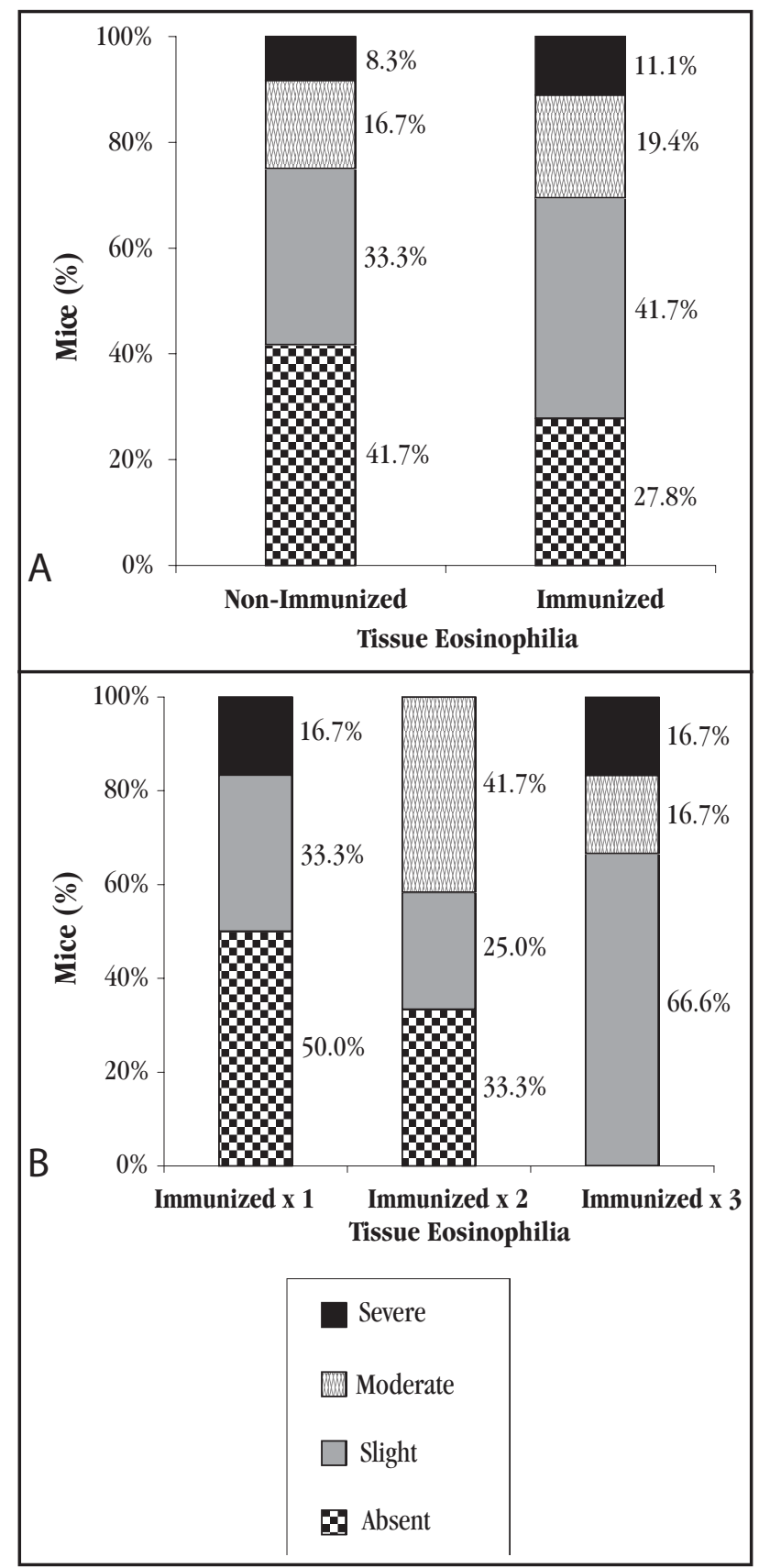

Figure 3 - Distribution of mice in relation to the intensity of eosinophilia in tissue inflammatory processes, according to: $A$ - immunization with Trypanosoma cruzi-like strain RM1 $(p=0.84) ; B$ - number of inoculations $(p=0.015)$.

\section{DISCUSSION}

The search for vaccines against parasitic diseases is complex, for three main factors: difficulties in reproducing natural infection conditions in the laboratory, parasite survival strategies and the requirement for effective protection for the whole organism, observed either in the bloodstream or in tissue.

Some studies have reported decreased parasitemia reduction as a protection parameter against Trypanosoma cruzi infection ${ }^{34}$. Nevertheless, in several of them, there was no association with the histopathological analysis. Mice chronically infected for one year with Trypanosoma cruzi strain Y and challenged with this 
same strain presented decreased parasitemia ${ }^{27}$, regardless of whether total protection was shown. Similar cases tend to occur in studies using trypanosomatids strains isolated from other reservoirs, due to the high antigenic similarity between these isolates and Trypanosoma cruzi. In our findings, even though the immunological protection was suggested by the parasitemia levels, this effect was invalidated by the histopathological analysis.

Despite the non-induction of a sterile immune response, this and some other studies describing partial protection should not be discarded. The vector infection during blood meals from animals immunized with attenuated or inactivated strains and challenged against virulent strains was lower than in non-immunized animals ${ }^{4}$. These authors suggested that interference in the domestic cycle of Chagas disease possibly occurred via vaccination of animal reservoirs which are in contact with humans in endemic areas, such as dogs immunized with epimastigotes of Trypanosoma rangeli ${ }^{6}$.

In order to induce effective protection from a vaccine, appropriate immune response activation is required. In Chagas disease, the main response involved in infection resistance is the $T_{H} 1$-type immune reaction $^{23}$. In this context, participation of adjuvants becomes important because of their ability to focus the immunological response to a cellular or humoral pattern that depends on the activated T-cell populations and the cytokine profile produced. In the present study, we used Freund's adjuvant, which can generate toxic effects in spite of its $\mathrm{T}_{\mathrm{H}} 1$-type stimulating properties ${ }^{33}$, thereby leading to controversy relating to protection induction ${ }^{20}$.

One important point to be discussed regarding immunization against Trypanosoma cruzi concerns the pathogenic mechanisms during the chronic phase, such as parasite persistence and the role of autoimmunity ${ }^{1522} 2637$, which still remain unclear. Regarding parasite persistence, some authors believe that there is an association between increased parasitemia and the degree of lesions observed ${ }^{22} 37$, as demonstrated by blood and tissue PCR and immunohistochemistry ${ }^{52}$. In the present study, the JG strain was more infective than the VIC strain was, although the two strains presented similar pathogenicity. Furthermore, although the mouse immunization demonstrated decreased parasitemia, the severity of the lesions in those animals was higher than in the non-immunized animals. Further studies on Trypanosoma cruzispecific PCR and immunohistochemistry are needed in order to detect the presence of parasite DNA or antigens in tissue specimens from the animals studied. Indeed, the previous findings suggest that parasitemia observed during the acute phase may not always be associated with the degree of lesions during the chronic phase, which suggests an autoimmune mechanism ${ }^{15}{ }^{19}$.

Prior to searching for a vaccine that confers total protection, knowledge of the immune response against Trypanosoma cruzi and how the immunoregulatory mechanisms drive the parasite infection is essential. Kierszenbaum ${ }^{24}$ queried the autoimmune component in Chagas disease because of the great delay in producing tissue lesions (as much as decades after infection), in comparison with other immunological diseases in which autoreactive $\mathrm{T}$ cells and autoantibodies are responsible for sudden progression lesions. Thus, the presence of eosinophils in inflammatory heart infiltrates has been correlated with the severity of human chronic Chagas myocarditis ${ }^{29}{ }^{30}$, suggesting possible pathogenic mechanisms other than the autoimmune component, defined by a substantial imbalance in the immunological system. In the present study, we noticed high numbers of eosinophils in tissue lesions, particularly in skeletal muscles. With regard to the immunized mice, there was a positive association between the number of Trypanosoma cruzi-like strain RM1 inoculations and eosinophilia intensity. These findings suggest that the number of cells present in histopathological lesions and the cell population type can be considered to be parameters for evaluating infection severity in the tissue $e^{30}$ and the prognosis for Chagas disease patients.

Because of increased presence of eosinophils in inflammatory infiltrates caused by the number of immunizations, and the possible relationship between these cells and the intensity of tissue lesions, the effect of reinfection in Chagas disease cases needs to be discussed. Animals reinfected with Trypanosoma cruzi strains presented greater electrocardiographic abnormalities than did those infected just once ${ }^{11}$. In addition, a study using three Trypanosoma cruzi strains of different biodemes demonstrated greater histopathological damage in triple infected mice, which was not accompanied by exacerbated parasitemia or tissue parasitism ${ }^{1}$. A similar phenomenon was described in the present study using the Trypanosoma cruzi-like strain RM1 isolated from bats.

In endemic areas, people are subject to several reinfections during their lives. If this process is responsible for increased morbidity in Chagas disease cases, the ideas of continuous vector control, screening of blood donors and improvement of local housing ${ }^{16}$ are reinforced and the effectiveness of a vaccine from attenuated or inactivated Trypanosoma cruzi strains becomes a controversial factor.

Therefore, the development of protection against Chagas disease presents several issues. Research using trypanosomatids isolated from animal reservoirs is important for clarifying the virulence and pathogenicity factors of the disease and for use as a model in immunological and biochemical studies on Trypanosoma cruzi. After induction of partial protection via previous inoculation with these trypanosomatids, characterization of enzymes and surface antigens is needed in order to reveal new targets for vaccines.

Although immunization against Trypanosoma cruzi is unlikely to provide efficient sterile immunity ${ }^{17}$, the decreased parasitemia associated with accurate immunomodulation could be effective in reducing the extent of tissue lesions, thereby avoiding chronic progression of Chagas disease and mortality.

\section{REFERENCES}

1. Andrade SG, Campos RF, Sobral KSC, Magalhães JB, Guedes RSP, Guerreiro ML. Reinfections with strains of Trypanosoma cruzi of different biodemes as a factor of aggravation of myocarditis and myositis in mice. Revista da Sociedade Brasileira de Medicina Tropical 39: 1-8, 2006.

2. Barreto MP, Ribeiro RD, Ferrioli Filho F. Estudos sobre reservatórios e vectores silvestres do Trypanosoma cruzi. LVII - Infecção natural do Phyllostomus hastatus hastatus (Tallas, 1767) pelo Trypanosoma cruzi. Revista Brasileira de Biologia 34: 615-622, 1974. 
3. Basombrío MA, Arredes HR, Rossi R, Raspi EM. Histopathological and parasitological evidence of immunization of mice against challenge with 17 wild isolates of Trypanosoma cruzi. International Journal for Parasitology 16: 375-380, 1986.

4. Basombrío MA, Mora MC, Segura MA. Protección imunológica contra la enfermedad de Chagas: efectos independientes sobre infección, diseminación y lesiones por Trypanosoma cruzi. Medicina (Buenos Aires) 49: 191-196, 1989.

5. Basquiera AL, Sembaj A, Aguerri AM, Omelianiuk M, Guzman S, Barral JM, Caeiro TF, Madoery RJ, Salomone 0. A. Risk progression to chronic Chagas cardiomyopathy: influence of male sex and of parasitaemia detected by polymerase chain reaction. Heart 89: 1186-1190, 2003.

6. Basso B, Castro I, Introini V, Gil P, Truyens C, Moretti E. Vaccination with Trypanosoma rangeli reduces the infectiousness of dogs experimentally infected with Trypanosoma cruzi. Vaccine 25: 3855-3858, 2007.

7. Basso B, Moretti ERA, Vottero-Cima E. Immune response and Trypanosoma cruzi infection in Trypanosoma rangeli-immunized mice. The American Journal of Tropical Medicine and Hygiene 44: 413-419, 1991.

8. Bento EC. Morcegos do Triângulo Mineiro e sua associação com tripanossomatídeos, filarídeos, fungos, vírus rábico e ectoparasitos. Dissertação de Mestrado, Universidade Federal do Triângulo Mineiro, Uberaba, MG, 2006.

9. Breganó JW, Picão RC, Graça VK, Menolli RA, Jankevicius SI, Pinge-Filho P, Jankevicius JV. Phytomonas serpens, a tomato parasite, shares antigens with Trypanosoma cruzi that are recognized by human sera and induce protective immunity in mice. FEMS Immunology and Medical Microbiology 39: 257-264, 2003.

10. Brener Z. Therapeutic activity and criterion of cure on mice experimentally infected with Trypanosoma cruzi. Revista do Instituto de Medicina Tropical de São Paulo 4: 389-396, 1962.

11. Bustamante JM, Rivarola HW, Fernández AR, Enders JE, Fretes R, Palma JA, Paglini-Oliva PA. Trypanosoma cruzi reinfections in mice determine the severity of cardiac damage. International Journal for Parasitology 32: 889-896, 2002.

12. Camargo EP. Growth and differentiation in Trypanosoma cruzi. I - Origin of metacyclic trypanosomes in liquid media. Revista do Instituto de Medicina Tropical de São Paulo 6: 93-100, 1964.

13. Cappa SMG, Pesce UJ, Cantarella AI, Schmuñis GA. Trypanosoma cruzi: Protection of mice with epimastigote antigens from immunologically different parasite strains. Experimental Parasitology 35: 179-186, 1974.

14. Costa F, Franchin G, Pereira-Chioccola VL, Ribeirão M, Schenkman S, Rodrigues MM. Immunization with a plasmid DNA containing the gene of trans-sialidase reduces Trypanosoma cruzi infection in mice. Vaccine 16: 768-774, 1998.

15. Cunha-Neto E, Coelho V, Guilherme L, Fiorelli A, Stolf N, Kalil J. Autoimmunity in Chagas' disease - Identification of cardiac myosin-B13 Trypanosoma cruzi protein crossreactive T cell clones in heart lesions of a chronic Chagas' cardiomyopathy patient. The Journal of Clinical Investigation 98: 1709-1712, 1996.

16. Dias JCP, Silveira AC, Schofield CJ. The impact of Chagas disease control in Latin America - a review. Memórias do Instituto Oswaldo Cruz 97: 603-612, 2002.

17. Dumonteil E. Review Article. DNA vaccines against protozoan parasites: advances and challenges. Journal of Biomedicine and Biotechnology (on line) 2007: ID 90520, p. 1-11, 2007.

18. Funayama GK, Barreto MP. Estudos sobre reservatórios e vectores silvestres do Trypanosoma cruzi. LIV - Infecção natural do morcego, Epitesicus brasiliensis brasiliensis (Desmarest, 1819) pelo Trypanosoma cruzi. Revista Brasileira de Biologia 33: 439-444, 1973.

19. Gironès N, Fresno M. Etiology of Chagas disease myocarditis: autoimmunity, parasite persistence, or both? Trends in Parasitology 19: 19-22, 2003.

20. González J, Araguth MF, Yoshida N. Resistance to acute Trypanosoma cruzi infection resulting from immunization of mice with a 90-kilodalton antigen from metacyclic trypomastigotes. Infection and Immunity 59: 863-867, 1991.
21. Grounds MD, Torrisi J. Anti-TNF- $\alpha$ (Remicade $\left.{ }^{\circledast}\right)$ therapy protects dystrophic skeletal muscle from necrosis. The FASEB Journal 18: 676-682, 2004.

22. Higuchi ML, Benvenuti LA, Reis MM, Metzger M. Pathophysiology of the heart in Chagas' disease: current status and new developments. Cardiovascular Research 60: 96-107, 2003.

23. Hoft DF, Schnapp AR, Eickhoff CS, Roodman ST. Involvement of CD $4^{+} \mathrm{T}_{\mathrm{H}} 1$ cells in systemic immunity protective against primary and secondary challenges with Trypanosoma cruzi. Infection and Immunity 68: 197-204, 2000.

24. Kierszenbaum F. Chronic chagasic tissue lesions in the absence of Trypanosoma cruzi: a proposed mechanism. Parasitology Today 12: 414-415, 1996.

25. Lages-Silva E, Crema E, Ramírez LE, Macedo AM, Pena SD, Chiari E. Relationship between Trypanosoma cruzi and human chagasic megaesophagus: blood and tissue parasitism. The American Journal of Tropical Medicine and Hygiene 65: 435-441, 2001.

26. Leon JS, Engman DM. Autoimmunity in Chagas heart disease. International Journal for Parasitology 31: 555-561, 2001.

27. Marinho CRF, Bastos KRB, Sardinha LR, Grisotto MG, Lima MRI, Alvarez JM. Challenge of Trypanosoma cruzi chronically infected mice with trypomastigotes activates the immune system and reduces subpatent parasitemia levels. Journal of Parasitology 90: 516-523, 2004.

28. Menezes H. Active immunization of mice with the avirulent $Y$ strain of Trypanosoma cruzi against heterologous virulent strains of the the same parasite. Revista do Instituto de Medicina Tropical de São Paulo 11: 335-342, 1969.

29. Molina HA, Kierszenbaum F. A study of human myocardial tissue in Chagas' disease: distribution and frequency of inflammatory cell types. International Journal for Parasitology 17: 1297-1305, 1987.

30. Molina HA, Kierszenbaum F. Kinetics of development of inflammatory lesions in myocardial and skeletal muscle in experimental Trypanosoma cruzi infection. Journal of Parasitology 74: 370-374, 1988.

31. Pinge-Filho P, Peron JP, Moura TR, Menolli RA, Graça VK, Estevão D, Tadokoro CE, Jankevicius JV, Rizzo LV. Protective immunity against Trypanosoma cruzi provided by oral immunization with Phytomonas serpens: role of nitric oxide. Immunology Letters 96: 283-290, 2005.

32. Ramírez LE, Lages-Silva E, Soares Júnior JM, Chapadeiro E. The hamster (Mesocricetus auratus) as experimental model in Chagas' disease: parasitological and histopathological studies in acute and chronic phases of Trypanosoma cruzi infection. Revista da Sociedade Brasileira de Medicina Tropical 27: 163-169, 1994.

33. Revelli S, Bottasso 0, Moreno H, Valenti J, Nocito A, Amerio N, Morini J. La enfermedad del adyuvante en ratas infectadas experimentalmente con Trypanosoma cruzi. Revista do Instituto de Medicina Tropical de São Paulo 28: 154-159, 1986.

34. Santos VM, Lima MA, Cabrine-Santos M, Marquez DS, Pereira GA, Lages-Silva E, Ramírez LE. Functional and histopathological study of the pancreas in hamsters (Mesocricetus auratus) infected and reinfected with Trypanosoma cruzi. Parasitology Research 94: 125-133, 2004.

35. Sepulveda P, Hontebeyrie M, Liegeard P, Mascilli A, Norris KA. DNA-Based immunization with Trypanosoma cruzi complement regulatory protein elicits complement lytic antibodies and confers protection against Trypanosoma cruzi infection. Infection and Immunity 68: 4986-4991, 2000.

36. Souza MC, Reis AP, Silva WD, Brener Z. Mechanism of acquired immunity induced by "Leptomonas pessoai" against Trypanosoma cruzi in mice. Journal of Protozoology 21: 579-584, 1974.

37. Tarleton RL. Parasite persistence in the aetiology of Chagas disease. International Journal of Parasitology 31: 550-554, 2001.

38. World Health Organization. New global effort to eliminate Chagas disease. Weekly epidemiological record 82: 259-260, 2007. 